\title{
EFFECT OF VITAMIN E ON POLYCYSTIC OVARY SYNDROME INDUCED BY DEHYDROEPIANDROSTERONE IN FEMALE ALBINO MICE: HISTOLOGICAL STUDY
}

\author{
SUHERA M. ABURAWI ${ }^{*}$, SOAD A. TREESH ${ }^{2}$, HABIBA A. EL JAAFARI ${ }^{3}$, MEDEHA \\ T. EL GHEDAMSI ${ }^{1}$, NAIROUZ A. NAFATI ${ }^{1}$, OMAIMA A. BENMAHMOUD ${ }^{1}$, MARWA \\ ALMAJRY ${ }^{1}$ AND NAEMA SHEBANI ${ }^{3}$ \\ ${ }^{1}$ Department of Pharmacology and Clinical Pharmacy, Faculty of Pharmacy, University of \\ Tripoli, Libya \\ ${ }^{2}$ Department of Histology and Medical Genetics, Faculty of Medicine, University of Tripoli, \\ Libya \\ ${ }^{3}$ Department of Zoology, Faculty of Science, University of Tripoli, Libya
}

Published online: 23 November 2021

To cite this article: SUHERA M. ABURAWI, SOAD A. TREESH, HABIBA A. EL JAAFARI, MEDEHA T. EL GHEDAMSI, NAIROUZ A. NAFATI, OMAIMA A. BENMAHMOUD, MARWA ALMAJRY \& NAEMA SHEBANI (2021) Effect of vitamin E on polycystic ovary syndrome induced by dehydroepiandrosterone in female albino mice: Histological study, Malaysian Journal of Pharmaceutical Sciences. 19(2): 111-130. https://doi.org/10.21315/ mjps2021.19.2.8

To link to this article: https://doi.org/10.21315/mjps2021.19.2.8

\begin{abstract}
Polycystic ovary syndrome (PCOS) is the most common endocrine disorder of reproductiveaged women. Vitamin $E$ is used in combination with clomid, metformin, melatonin or other drugs to ameliorate and improve the symptoms of PCOS. The aim is to investigate the histological effect of vitamin E on PCOS. PCOS model using dehydroepiandrosterone (DHEA) was adopted. Female mice were divided into eight groups $(n=6)$. Group 1 was administered with 1\% T80; Group 2 was administered with DHEA; Group 3 was administered with clomid; Group 4 was administered with vitamin E; Group 5 was administered with DHEA and vitamin E; drugs were administered for 20 days. Group 6 was administered with DHEA per day for 20 days followed by clomid, a dose per day, for the next 10 days; Group 7 was administered with DHEA per day for 20 days followed by vitamin E, a dose per day, for the next 10 days; Group 8 was administered with DHEA every day for 20 days followed by no treatment for the next 10 days. Mice were sacrificed, at the end of experiment, by neck dislocation, ovary was surgically separated and kept in 10\% formalin for histological analysis. DHEA administration produces PCOS changes in ovary. Clomid did not improve $P C O S$ induced by DHEA, while vitamin E ameliorates PCOS to nearly normal. Vitamin E showed marked recovery of the ovarian tissue with the presence of many follicles in the
\end{abstract}

"Corresponding author: smaburawi@gmail.com

(c) Penerbit Universiti Sains Malaysia, 2021. This work is licensed under the terms of the Creative Commons Attribution (CC BY) (http://creativecommons.org/licenses/by/4.0/). 
various stages of development, indicating normal oogenesis. Follicles showed normal granulosa layer with defined thecal layers. The presence of corpora lutea was also seen, indicating that vitamin $E$ treatment restore normal estrous cycle.

Keywords: PCOS, DHEA, Vitamin E, Clomid, Mice

\section{INTRODUCTION}

Polycystic ovary syndrome (PCOS) is the most common endocrine disorder of reproductiveaged women (Diamanti-Kandarakis et al. 1999; Goodman et al. 2015). This syndrome includes various criteria such as hyperandrogenism (Goodman et al. 2015; Lerchbaum et al. 2014), menstrual irregularity, oligomenorrhea, amenorrhea, infertility (Diamanti-Kandarakis et al. 1999; Pannill 2002), and polycystic ovary morphology (Goodman et al. 2015; Lerchbaum et al. 2014). PCOS is associated with obesity and metabolic abnormalities, such as dyslipidemia and insulin resistance. It can be clinically expressed with acne, hirsutism or androgen-dependent alopecia (Diamanti-Kandarakis et al. 1999) and elevated serum luteinising hormon (LH) levels (The Rotterdam ESHRE/ASRM-Sponsored PCOS Consensus Workshop Group 2004).

Puberty is initiated with the maturation of the hypothalamic-pituitary ovarian axis and secretion of gonadotrophin-releasing hormone $(\mathrm{GnRH})$, the activity of which is suppressed during childhood (Roe and Dokras 2011). The pathophysiology of the PCOS encompasses inherent ovarian dysfunction that is strongly influenced by external factors, such as disturbances of the hypothalamic-pituitary-ovarian axis and hyperinsulinemia, these disturbances affects both ovarian androgen production and oocyte development (Balen 2004).

Clomid (clomiphene citrate) is a nonsteroidal, ovulatory stimulant (Practice Committee of the American Society for Reproductive Medicine 2013). It is used to treat infertility in women who do not ovulate, including those who have PCOS. Its use is associated with a higher probability of having twins (The American Society of Health-System Pharmacists 2017). Clomid inhibits oestrogen receptors in the hypothalamus, inhibiting negative feedback of oestrogen on gonadotropin release, leading to up-regulation of the hypothalamic-pituitary-gonadal axis (Drug Bank 2011).

Vitamin $E$ is a fat-soluble vitamin with potent antioxidant activities, naturally found in eight chemical forms (Traber 2006); the most common biologically active form is alphatocopherol (Traber 2006; Rizvi et al. 2014). It is important for normal cell growth and function (Traber 2006).

Vitamin $E$ has a role as a potent antioxidant. It maintains the integrity and bioactivity of long-chain polyunsaturated fatty acids in the membranes of cells and prevents its oxidation. It protects body tissue from damage caused by free radicals, which can harm cells, tissues and organs. Vitamin E has a role in anti-aging (Traber and Atkinson 2007; Mangialasche et al. 2013).

Recently, vitamin $\mathrm{E}$ is used as a supplementary for the treatment of endocrinopathy in reproductive age women, such as PCOS, insulin resistance and excess androgen levels (Amini et al. 2015).

Malay J Pharm Sci, Vol. 19, No. 2 (2021): 111-130 


\section{AIM OF THE WORK}

Vitamin E is used in combination with clomid, metformin, melatonin or other drugs to ameliorate and improve the symptoms and signs of PCOS case. The aim of this work is to investigate the histological effect of vitamin E alone on PCOS induced by dehydroepiandrosterone (DHEA) using female albino mice.

\section{METHOD}

\section{Drugs}

DHEA was bought from Natrol LLC Chatsworth, USA. Vitamin E was obtained from Noventis, Vietnam. Clomid was obtained from Wockhardt Mumbai, India.

\section{Animals}

Female albino mice (weight ranged from 25-35 gm) were inbred in animal house of Faculty of Pharmacy, University of Tripoli. Standard mice food pellet diet and water were free available during the experiment. The animals were kept at room temperature $\left(20-25^{\circ} \mathrm{C}\right)$ and on $12 \mathrm{~h}$ dark/light cycle. Animals were kept in laboratory for at least one day before testing to acclimate with a new environment.

This experimental research on animals was conducted according to ethical rules of the Department of Pharmacology and Clinical Pharmacy, Faculty of Pharmacy, the University of Tripoli.

\section{Experimental Design}

The model prescribed by Oakley et al. (2011) was adopted. Female mice were divided into eight group, each group of six mice. Group 1 was administered with 1\% T80 of a dose $5 \mathrm{~mL} / \mathrm{kg}$ (Aburawi and Baayo 2017) per day for 20 days; Group 2 was administered with DHEA of a dose $6 \mathrm{mg} / \mathrm{kg}$ per day for 20 days; Group 3 was administered with clomid of a dose $10 \mathrm{mg} / \mathrm{kg}$ (Chen et al. 2016) per day for 20 days; Group 4 was administered with vitamin $\mathrm{E}$ of a dose $100 \mathrm{mg} / \mathrm{kg}$ (Lobato et al. 2010) per day for 20 days; Group 5 was administered with DHEA and vitamin E per day for 20 days; Group 6 was administered with DHEA per day for 20 days followed by clomid, a dose per day, for the next 10 days; Group 7 was administered with DHEA per day for 20 days followed by vitamin E, a dose per day, for the next 10 days; Group 8 was administered with DHEA every day for 20 days followed by no treatment for the next 10 days. On the last day of treatment for each group, mice were sacrificed by neck dislocation, the abdomen was surgically opened, ovary was separated and kept in $10 \%$ formalin for histological analysis (Figure 1). 


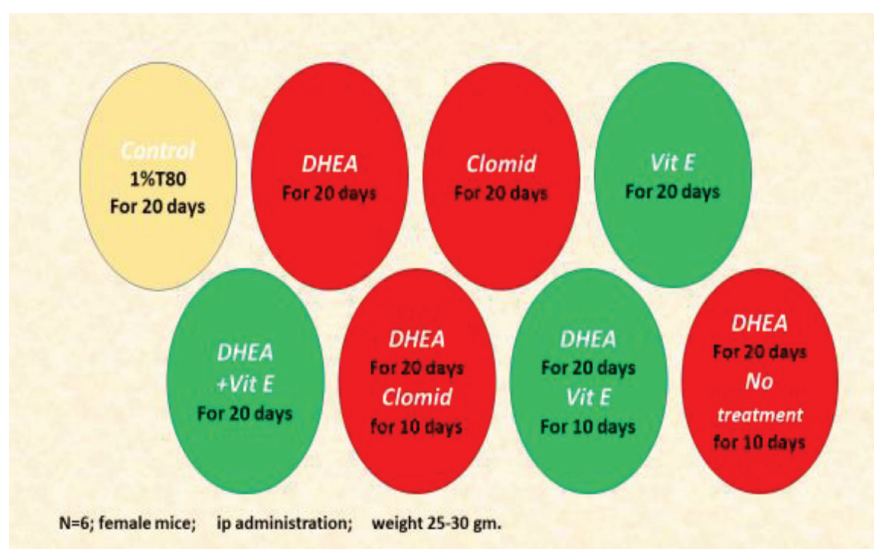

Figure 1: Design of the work.

\section{Histological Study}

At the end of the administration, mice were sacrificed, ovaries of treated mice were removed and fixed in $10 \%$ formalin for $48 \mathrm{~h}$. The fixed tissues were dehydrated in an ascending series of alcohol ranging from $50 \%$ to $100 \%$ (absolute). The dehydrated tissues were cleared in xylene (two changes), infiltrated and then embedded in paraffin wax. The ovaries were sectioned on a rotary microtome, sections were $5 \mu \mathrm{m}$ in thickness. The prepared sections were stained by routine methods using hematoxylin and eosin (H\&E) stain method (Bancroft and Gamble 2002).

The ovaries sections from each study group were evaluated for structural changes by examination under the microscope, and the different follicles and cysts types were carefully studied and photographed.

\section{RESULTS}

\section{Histological Results}

\section{Group 1: ovary control}

Examination of H\&E stain sections of control mice ovaries revealed that the ovaries were covered by a single layer of cuboidal epithelium.

The epithelium was separated from the underlying ovarian tissue by a layer of collagenous fibres tunica albuginea. In the ovarian cortex, the primordial follicles and different forms of growing follicles (primary and secondary) were seen in the ovarian cortex, underneath the tunica albuginea.

Mature or Graafian follicle was a larger follicle, located near the surface. The corpus luteum was formed of both granulosa and theca lutein cells, which were polyhedral cells containing large spherical nuclei and large amount of vacuolated cytoplasm.

The stroma of the ovary was formed of connective tissue (interstitial tissue) showing collagen fibres and blood vessels (Figure 2). 


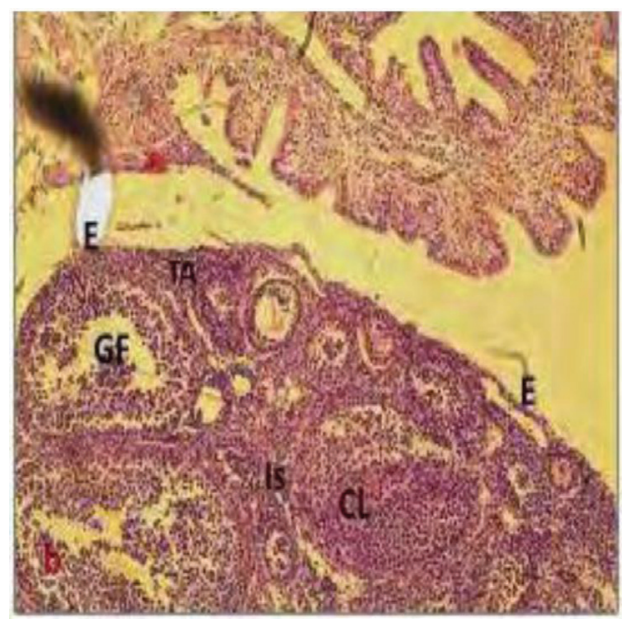

Figure 2: Control treated group; $\mathrm{E}=$ epithelium, $\mathrm{F}=$ Graffian follicle, IS = interstitial tissue, $\mathrm{CL}=$ corpus luteum, $\mathrm{TA}=$ tunica albuginea $(10 \times)$.

\section{Group 2: DHEA treated group}

Sections of the ovary injected with DHEA showed a significant decrease in the number of preovulatory follicles and corpora lutea in the ovaries of this group in comparison to control. However, there was no significance change in the number of primary, preantral and antral follicles; the atretic follicles were higher than control group.

There were various degrees of atresia, from follicles with nuclear pyknosis to corpus fibrosum. Corpora lutea were not observed.

We conclude that DHEA administration results in increased ovarian apoptosis and in larger follicle size, thereby producing a characteristic cystic and atretic appearance in the mouse ovary (Figure 3).

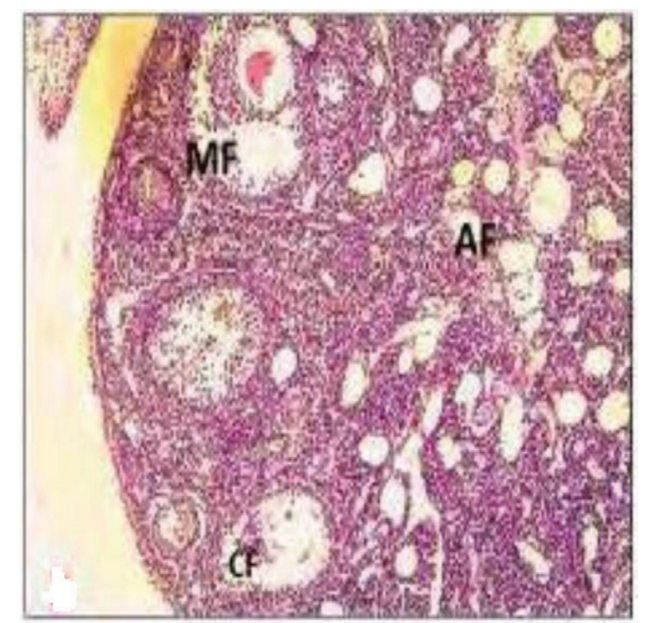

Figure 3: DHEA treated group; $\mathrm{MF}=$ mature follicle, $\mathrm{AF}=$ atretic follicle, $\mathrm{CF}=$ cystic follicle $(10 \times)$. 


\section{Group 3: clomid treated group}

An increasing number of fluid-filled cystic follicles was observed. The ovaries were homogenous and contained significant large antral follicle; there were significantly less mature and ovulated follicles.

The presence of Graafian and corpora lutea indicates imminent and recent ovulation. Mice ovaries showed a thick tunica albuginea, scarce primary and growing follicles and numerous atretic follicles.

The tertiary follicles were considerably distended and cystic (polycystic ovaries). The granulosa and theca cells appeared normal. Some stroma cells were hypertrophied. The ovaries showed a high number of atretic follicles.

The germinal epithelium showed abnormal structure including the appearance of many degrees of invaginations along its surface. The cuboidal cells of the germinal epithelium became flattened with deeply stained nuclei and lost their arrangement (Figure 4). No other alterations were evident.

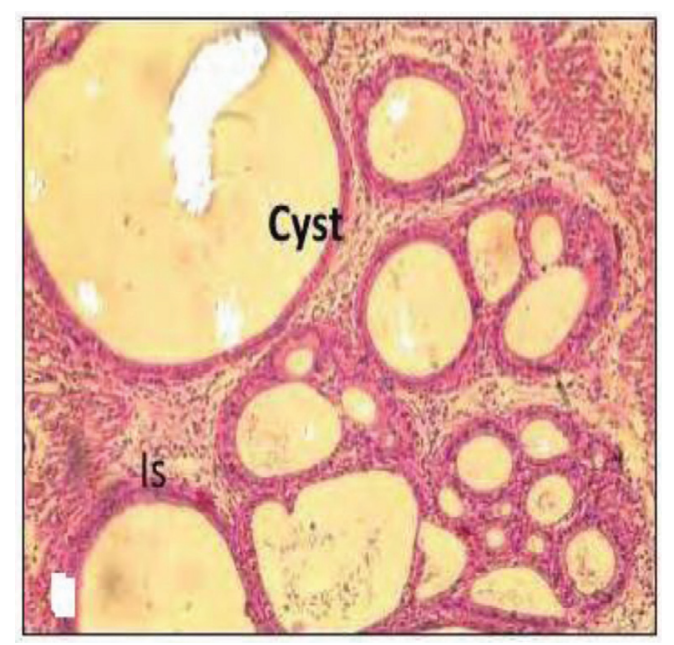

Figure 4: Clomid treated group; Cyst, IS = interstitial tissue (10x).

\section{Group 4: vitamin E treated group}

The tunica albuginea covering the ovary appeared normal. There was a number of corpus luteum and few numbers of primordial follicles. However, numerous blood vessels in interstitial tissue among atretic follicles were observed; also, the presence of growing follicle and atretic follicle were observed (Figure 5). 


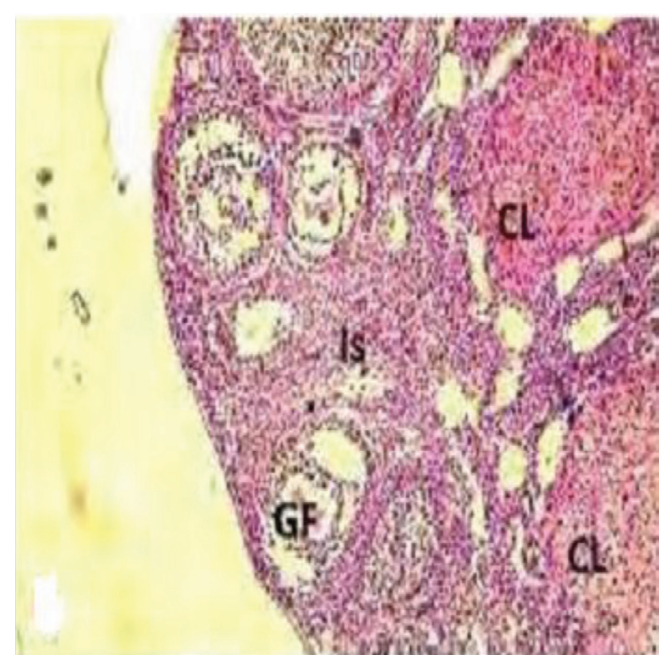

Figure 5: Vitamin E treated group; GF = Graffian follicle, IS = interstitial tissue, $\mathrm{CL}=$ corpus luteum (10x).

\section{Group 5: DHEA and vitamin E treated group}

Sections of mice ovary injected with DHEA and vitamin E showed a decrease in the number of preovulatory follicles and corpora lutea, in comparison to control.

The result is as described in Group 2, in addition to increasing the number of fluidfilled cystic follicles. Corpora lutea were not observed (Figure 6).

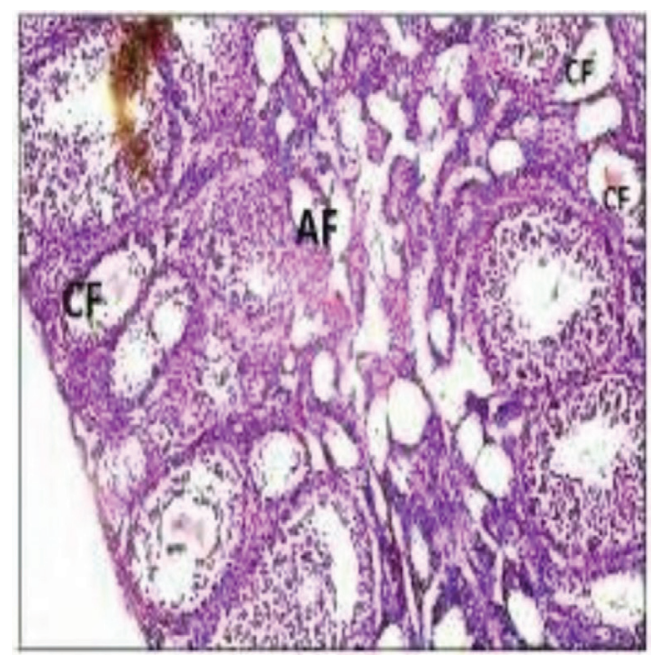

Figure 6: DHEA and vitamin E treated group; $C F=$ cystic follicle, $A F=$ atretic follicle (10x). 


\section{Group 6: DHEA followed by clomid treated group}

Sections of mice ovary injected with DHEA followed by clomid showed a large number of degenerated follicles. The cuboidal cells of the germinal epithelium became flattened with deeply stained nuclei and lost their arrangement.

The ovarian stroma contained large number of vacuoles and atretic follicles of different sizes. Some abnormal Graafian follicles appeared with enlarged antrum and degenerated zona pellucid. The number of small, medium and large follicles decreased. Conversely, the number of atretic follicles showed a significant increase (Figure 7).

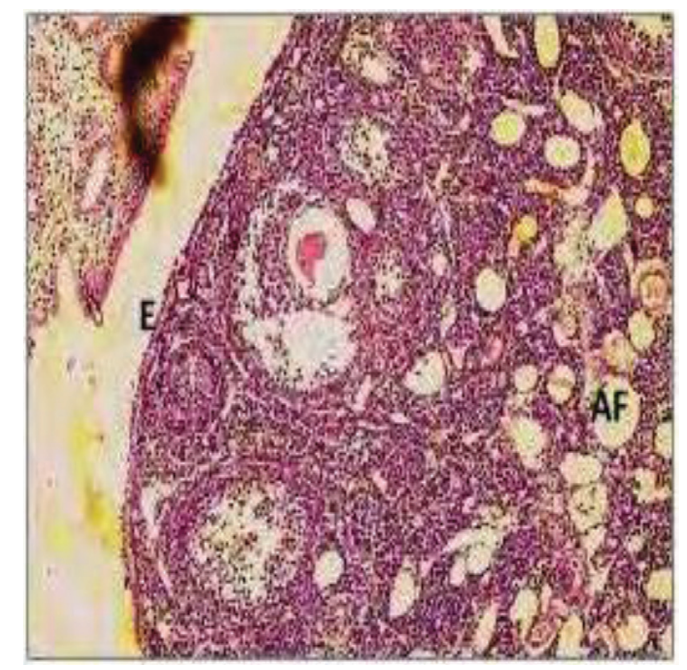

Figure 7: DHEA followed by clomid treated group; $\mathrm{E}=$ epithelium, $\mathrm{AF}=$ atretic follicle (10x).

\section{Group 7: DHEA followed by vitamin E treated group}

This group of vitamin E administration after DEHA resulted in a remarkable reduction in atratic follicles and the presence of intact secondary and mature follicles; some degenerated and cystic follicle were found.

The germinal epithelium and stroma of the ovary are normal. In conclusion, vitamin E could compensate the most adverse effects of DEHA treatment on ovary structure. It was seen that the application of vitamin E could increase the corpora lutea and the number of primary follicles and improve the main structural parameters of follicle in the late stages of follicular development (Figure 8). 


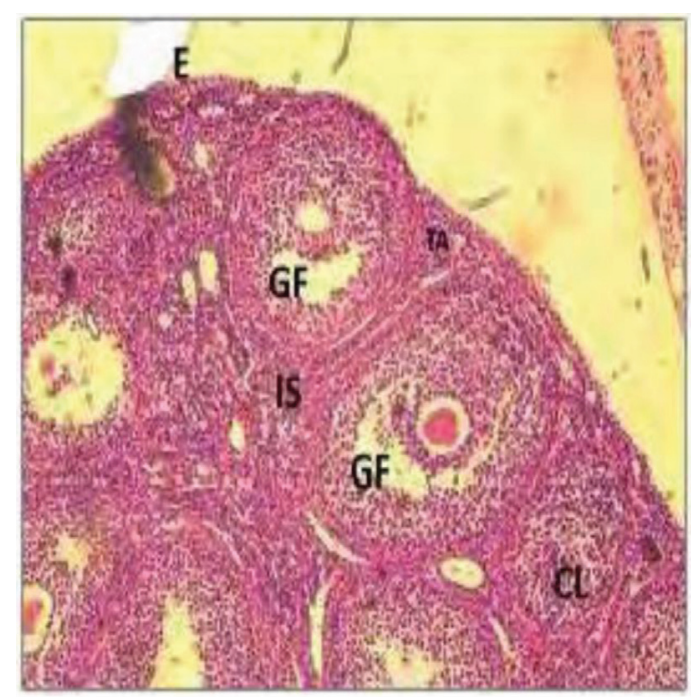

Figure 8: DHEA followed by vitamin E treated group; $\mathrm{E}=$ epithelium, GF = Graffian follicle, IS = interstitial tissue $(10 \times)$.

\section{Group 8: DHEA treated group followed by no treatment}

This group showed similar effect of DHEA administration as observed in Group 2, DHEA treated group.

\section{DISCUSSION}

In PCOS, high local androgen concentrations are responsible for anovulation by direct effect on the ovary. Androgen-induced follicular atresia is thought to occur by entry of androgens into the granulosa layer of pre-antral follicles, where they bind to the cell receptors and cause cell death. Androgens cause deterioration of follicles by increasing the number of pyknotic granulosa cells and degenerating oocytes (De Leo et al. 1998). Rats with PCOS showed no ovulation, which is due to the high levels of estradiol and testosterone produced by interstitial cells, leading to lack of control in the hypothalamic region with inhibition of pituitary function (Lombardi et al. 2014). Level of antioxidant vitamins like vitamin $E$ is also decreased in PCOS patients (Naidu et al. 2013).

Androgenisation of animals is used to induce symptoms that resemble PCOS (Paixão et al. 2017). PCOS was induced by DHEA and the effect of clomid or vitamin E on the development of the follicular growth was observed based on histological investigation.

Histopathological study of PCOS groups showed the presence of atretic follicles, the formation of more than subcapsular cysts lined with thin attenuated layer of granulosa cells, thickened ovarian capsule and hyperplasia of theca interna cells in the ovary (Rezvanfar et al. 2012; Jadhav, Menon and Shailajan 2013).

Insulin resistance is the main cause in the pathogenesis of PCOS (Fenkci et al. 2003; Phinney and Volek 2019); therefore, targeting insulin resistance may result in a list of benefits for women with PCOS, including hormonal, metabolic and ovulatory (and fertility) improvements (Pasquali and Gambineri 2009). Insulin resistance and decreased antioxidant 
vitamins in PCOS subjects and oxidative stress may be a cause for the progression of PCOS (Naidu et al. 2013). Insulin resistance may be central to the etiology of PCOS (DiamantiKandarakis and Dunaif 2012).

Insulin receptors have been demonstrated in ovaries (Poretsky et al. 1999; Dunaif et al. 1995); insulin can stimulate ovarian growth and steroid genesis. Insulin increases intra ovarian androgens, disrupts normal follicular genesis, causes development of multiple ovarian cysts and ovarian enlargement (Naidu et al. 2013). It was found that androgens can directly impair beta cell function by inducing mitochondrial dysfunction in vitro in an androgen receptor dependent manner. Therefore, the increase in androgens in female rats can impair glucose-stimulated insulin secretion partly through disruption of pancreatic beta cell mitochondrial function (Wang et al. 2015).

\section{Control Treated Group}

In the control group, the ovary was covered by a single layer of cuboidal epithelium, which was separated from the underlying ovarian tissue by a layer of collagenous fibres, tunica albuginea. In the ovarian cortex, the primordial follicles and different forms of growing follicles (primary and secondary) were seen in the ovarian cortex, underneath the tunica albuginea. Mature or Graafian follicle was observed; the stroma of the ovary was formed of connective tissue (interstitial tissue) showing collagen fibres and blood vessels.

Healthy reproductive system requires a balance between free radicals and antioxidants (Fujii, luchi and Okada 2005); ovary is a metabolically active organ and, hence, is under a variety of stresses continuously. Reactive oxygen species (ROS) is released in connection with follicle rupture and is involved in the process (Sugino et al. 2004). In healthy condition, oxidative stress (OS) facilitates the following physiological female reproductive functions: oocyte maturation, folliculogenesis, ovarian steroidogenesis, luteolysis, ovulation, cyclical endometrial changes, menstruation, tissue remodeling, hormone signaling, tubal function and germ cell function (Agarwal, Gupta and Sharma 2005a).

Moderate OS levels are required for ovulation. The final stages of oocyte maturation are associated with fluctuations in cytokines, prostaglandins, proteolytic enzymes, nitric oxide and steroids; these increase the level of ROS, influencing ovarian blood flow and eventually facilitating follicle rupture (Agarwal, Gupta and Sharma 2005a).

Reproductive cells and tissues remain healthy when free radical production and the scavenging antioxidants remain in balance (Agarwal, Gupta and Sharma 2005b). ROS is controlled and kept at physiological levels within the ovary by various antioxidant systems, including catalase, vitamin E, glutathione and carotenoids (Agarwal Gupta and Sharma 2005b). As the levels of ROS become pathologically elevated, antioxidants begin to work and help minimise the oxidative damage and then repair or prevent it altogether (Sekhon et al. 2010; Agarwal and Allamaneni 2004a). Imbalance related to increased ROS or decreased antioxidants causes the oxidative stress, which may lead to anovulation, dysfunctional oocytes and fertilisation failure (Agarwal et al. 2012).

\section{Polycystic Model Induced by DHEA}

DHEA is a weak endogenous steroid hormone (Nippold and Nair 1998; Mo, Lu and Simon 2006) that acts as a precursor in the production of sex hormones (Olech and Merrill 2005). It is produced in the adrenal glands, and also by the gonads and the brain (Rammouz, Lecanu and Papadopoulos 2011), where it functions as a metabolic intermediate in the biosynthesis of the androgen and oestrogen sex steroids (Mo, Lu and Simon 2006).

Malay J Pharm Sci, Vol. 19, No. 2 (2021): 111-130 
Injecting DHEA to mice for 20 days resulted in a significant decrease in the number of preovulatory follicles and corpora lutea in the ovaries of this group, in comparison to control. However, there was no significant change in the number of primary, preantral and antral follicles, while the atretic follicles were higher than in the control group. There was various degree of atresia, from follicles with nuclear pyknosis to corpus fibrosum. Corpora lutea were not observed. We conclude that DHEA administration results in increased ovarian apoptosis and in larger follicle size, thereby producing a characteristic cystic and atretic appearance in the mouse ovary. The dose used in this study of DHEA is sufficient to induce hyper-androgenised state, leading to ovulatory defect and formation of follicular cyst in the ovary.

It was found that administration (ip) of DHEA in a dose $6 \mathrm{mg} / \mathrm{kg}$ for 20 days, leads to changes in the follicular and morphological changes of ovary (Oakley et al. 2011). It has also been proposed that elevated testosterone disrupts the regulation of $\mathrm{GnRH}$ secretion (Zhang et al. 2013).

Some animal studies have shown that androgen suppresses progesterone receptor (PR) expression in the hypothalamus (Foecking et al. 2008; Lea, Clark and Tsutsui 2001). As progesterone, down-regulates $\mathrm{GnRH}$ secretion by activating progesterone receptor activity in the hypothalamus (Pastor et al. 1998; Goodman 1996), androgen-mediated suppression of progesterone receptor expression may ameliorate $\mathrm{GnRH}$ secretion. This altered release of gonadotropins will cause defects in follicle development, leading to failure to ovulate (anovulation) or be reduced leading to irregular ovulation (oligo-ovulation). The arrested follicle may thus form a cystic structure, leading to the polycystic ovarian phenotype and loss of fertility in PCOS (Oakley et al. 2011). PCOS showed that the ovaries contained numerous ovarian cysts with granulosa cell apoptosis, large number of interstitial cells and absence of corpora lutea, causing low percentage of cell proliferation in granulosa cells. The rate of cell proliferation in the theca interna is higher in the PCOS group compared to the control (Lombardi et al. 2014), facilitating the accumulation of interstitial cells in ovarian stroma, leading to the persistence of large concentrations of interstitial cells in the ovaries (Lombardi et al. 2012). Rats with PCOS showed no ovulation, due to the high levels of estradiol and testosterone produced by interstitial cells, leading to lack of control in the hypothalamic region with inhibition of pituitary function (Lombardi et al. 2014).

Oxidative stress arises from an imbalance between prooxidant molecules generated from aerobic metabolism and protective antioxidants (Agarwal et al. 2012). Oxidative stress influences the entire reproductive lifespan of woman. Reactive oxygen species may act as key signaling molecules in physiological processes, but at excess uncontrolled levels, they may also mediate pathological processes involving the female reproductive tract (Agarwal, Gupta and Sharma 2005a; Ruder et al. 2008).

A high free radical state can deplete protective antioxidants, as vitamin E, betacarotene, superoxide dismutase and catalase (Rahman 2007). Excessive ROS production may overpower the body's natural antioxidant defense system, creating an environment unsuitable for normal female physiological reactions. This, in turn, can lead to a number of reproductive diseases as PCOS (Agarwal et al. 2012).

\section{Vitamin E Treated Group}

In this study, the vitamin E treated group showed normal appearance of tunica albuginea covering the ovary; the presence of a number of corpus luteum and few numbers of primordial follicles were observed. Numerous blood vessels in interstitial tissue among atretic follicles, and the presence of growing follicle and atretic follicle are observed. 
Mice ovary injected with DHEA and vitamin E showed a decrease in the number of preovulatory follicles and corpora lutea in the ovaries of this group, in comparison to the control group. This group (DHEA and vitamin E) shows a similarity as group treated with DHEA only, in addition to increasing the number of fluid-filled cystic follicles. Corpora lutea were not observed.

Mice treated with vitamin E after induction of PCOS by DHEA resulted in a remarkable reduction in atretic follicles, and the presence of intact secondary and mature follicles; some degenerated and cystic follicle were observed. The germinal epithelium and stroma of the ovary are normal.

In conclusion, vitamin E could compensate the most adverse effects of DHEA administration on ovary structure; also, it was seen that the application of vitamin $E$ only could increase the corpora lutea, the number of primary follicles and improve the main structural parameters of follicle in the late stages of follicular development.

Antioxidants are molecules that act to stop the chain reaction and preserve the integrity of the cell. When body cells produce an abundance of ROS or there is a reduction in the body's antioxidant defense mechanism, oxidative stress starts (Ozkaya and Naziroglu 2010).

Under normal conditions, antioxidants act to oppose ROS production, scavenge existing free radicals and promote the repair of ROS-induced damage to cell structures (Agarwal and Allamaneni 2004b). Antioxidant supplementation increases the activity of antioxidant enzymes, while decreasing markers of oxidative stress such as malondialdehyde and lipid peroxides (Mier-Cabrera et al. 2009); also it has a potential to overcome reproductive disorders associated with infertility (Agarwal et al. 2012). Therefore, the antioxidant effects may serve as a therapeutic strategy to improve the level of circulating insulin and insulin sensitivity in PCOS patients with hyperinsulinemia (Fulghesu et al. 2002). Antioxidant treatment of PCOS may improve glucose control and peripheral insulin sensitivity and may reduce parameters of OS in hyperinsulinemic patients (Sekhon et al. 2010).

Nonenzymatic antioxidants, as vitamins $E$ (Sekhon et al. 2010), has the ability to scavenge ROS and prevent OS and cellular damage (Sekhon et al. 2010; Tahan et al. 2011), and has anti-inflammatory properties (Tahan et al. 2011).

It is suggested that vitamin $E$ acts as a scavenger protecting from peroxidation reaction (Naidu et al. 2013). Vitamin E is a potent chain breaking lipid soluble antioxidant. It reacts with lipid peroxyl radicals terminating the peroxidation chain reaction and thereby reducing oxidative damage (Naidu et al. 2013). Vitamin E, with antioxidant activity, reacts with lipid radicals produced during lipid peroxidation. This reaction produces oxidised a-tocopheroxyl radicals that can be transformed back to the active reduced form by reacting with other antioxidants, like ascorbate, retinol or ubiquinol (Buettner 1993; Traber and Stevens 2011).

Insulin resistance is predominantly seen in PCOS subjects (Naidu et al. 2013). Insulin resistance is considered the main cause in the pathogenesis of PCOS (Rosenfield and Ehrmann 2016). Insulin receptors in ovaries (Poretsky et al. 1999; Dunaif et al. 1995) can stimulate ovarian growth and steroid genesis and increase intra ovarian androgens, disrupt normal follicular genesis, cause development of multiple ovarian cysts and ovarian enlargement (Naidu et al. 2013). It has been postulated that elevated insulin (hyperinsulinemia) is important in the pathogenesis of endocrine abnormality in PCOS. Lowering insulin levels may produce favourable results in these patients (Baillargeon 2005).

Antioxidant supplementation showed an improvement in insulin sensitivity and restore redox balance in patients with PCOS (Sekhon et al. 2010). It was found that the levels of vitamin E was lower in patients with PCOS than in the control group (Hamad, Ahmad and Rasheed 2011). Ebrahimi et al. (2017) found that vitamin E supplementation for

Malay J Pharm Sci, Vol. 19, No. 2 (2021): 111-130 
12 weeks in PCOS women significantly improved indices of insulin resistance, total and free testosterone. Vitamin E improved insulin sensitivity and treated inflammation; therefore, it is the most effective treatment strategy for PCOS subjects (Rahmani et al. 2017). Vitamin E administration may improve the endometrial response via antioxidant and the anticoagulant effects, which may increase the blood supply to the follicles and the proliferating granulosa cells (Cicek et al. 2012). Vitamin E significantly improved gene expression of lipoprotein a $[L p(a)]$ and oxidised low-density lipoprotein (Ox-LDL), lipid profiles and biomarkers of oxidative stress (Rahmani et al. 2017). Therefore, vitamin E has a good potential as alternative therapy in the treatment of PCOS.

There is an increase in inflammatory cytokines in PCOS subjects resulting in increased risk for the development of infertility (Pawelczak et al. 2014). Vitamin $E$ supplementation in rats may significantly decreased gene expression of tumour necrosis factor alpha (TNF- $\alpha$ ) (Monteiro et al. 2012). Vitamin E can decrease gene expression related to inflammatory signaling pathways through specific enzymes involved in signal transduction modulation such as protein kinase $\mathrm{C}$, phosphatidylinositol 3-kinase, lipoxygenases, phospholipase A2 and diacylglycerol kinase (Azzi et al. 2004).

\section{Clomid Treated Group}

In this study, clomid produces an increase in the number of fluid-filled cystic follicles. The ovaries contained significant large antral follicle; there were significantly less mature and ovulated follicles. The presence of Graafian and corpora lutea indicates imminent and recent ovulation. The ovaries of the mice showed a thick tunica albuginea, scarce primary and growing follicles and numerous atretic follicles. The tertiary follicles were considerably distended and cystic (polycystic ovaries). The granulosa and theca cells appeared normal. Some stroma cells were hypertrophied. The ovaries showed a high number of atretic follicles. The germinal epithelium showed abnormal structure including the appearance of many degrees of invaginations along its surface. The cuboidal cells of the germinal epithelium became flattened with deeply stained nuclei and lost their arrangement.

Clomiphene citrate is a selective oestrogen-receptor modulator; it induces ovulation by inhibiting negative endogenous oestrogen feedback on the hypothalamic pituitary axis, resulting in an increase in follicle-stimulating hormone (FSH) secretion, follicular growth and ovulation (Homburg 2005). Clomid is used mainly in female infertility (Palomba et al. 2006). The use of clomid for ovulation induction continues to be the first-line therapy for most etiologies of female infertility (Frattarelli and Dempsey 2004).

Clomid is a non-steroidal compound, has a remarkable structural similarity to oestradiol (E2), which enables it to bind to E2 receptors in various tissues such as the hypothalamus, hypophysis, ovaries and the uterus and cervix. Clomid induces ovulation, by binding to the E2 receptors in the hypothalamus to create a state of hypoestrogenicity, causing an enhanced gonadotrophin-releasing hormone $(\mathrm{GnRH})$, the increased secretion of gonadotrophins induces ovulation (Usadi and Fritz 2008).

It was reported that clomid treatment caused ovarian enlargement; induced degenerative effects in the ovary (Duran and Raja 2007). The ovarian stroma contained large number of vacuoles, atretic follicles of different sizes and congested blood vessels; also, abnormal Graafian follicles appeared with enlarged antrum and degenerated zona pellucid, with a decrease in the number of ovarian follicles and an increase in atretic ones (Lamfon and Al-Matrafi 2013).

After treatment with DHEA followed by clomid, the ovary showed large number of degenerated follicles. The cuboidal cells of the germinal epithelium became flattened with deeply stained nuclei and lost their arrangement. The ovarian stroma contained a large 
number of vacuoles and atretic follicles of different sizes. Some abnormal Graafian follicles appeared with enlarged antrum and degenerated zona pellucid. The number of small, medium and large follicles decreased. Conversely, the number of atretic follicles showed a significant increase.

Administration of clomid alone in this study, produces its adverse effect on the histological analysis of ovary. Therefore, clomid did not ameliorates PCOS induced by DHEA.

\section{DHEA Followed No Treatment}

This group showed similar effect of DHEA administration as observed in Group 2, the DHEA treated group. Working on experimental animal model for disease could be reversed back to normal by time without treatment; Group 8 showed that irreversible PCOS histology and the improvement seen by vitamin E treatment after DHEA administration was due to vitamin E effect.

\section{CONCLUSION}

DHEA administration produce PCOS changes in ovary. Clomid in the dose used produce its adverse effect and it did not improve PCOS induced by DHEA. Vitamin E ameliorate the PCOS to nearly the normal. Vitamin E showed marked recovery of the ovarian tissue with the presence of many follicles in the various stages of development, indicating normal oogenesis. The follicles showed normal granulosa layer with defined thecal layers. The presence of corpora lutea was also seen, indicating that vitamin $E$ treatment restore normal estrous cycle.

\section{REFERENCES}

ABURAWI, S. M. \& BAAYO, S. A. (2017) Behavior effect of fluoxetine in presence of selenium using albino mice, International Journal of Pharmacology, Phytochemistry and Ethnomedicine, 7: 1-8.

AGARWAL, A. \& ALLAMANENI, S. (2004a) Oxidants and antioxidants in human fertility, Middle East Fertility Society Journal, 9(3): 187-197.

AGARWAL, A. \& ALLAMANENI, S. (2004b) Role of free radicals in female reproductive diseases and assisted reproduction, Reproductive BioMedicine Online, 9(3): 338-347. https://doi.org/10.1016/s1472-6483(10)62151-7

AgARWAL, A., APONTE-MELLADO, A., PREMKUMAR, B. J., SHAMAN, A. \& GUPTA, S. (2012) The effects of oxidative stress on female reproduction: A review, Reproductive Biology and Endocrinology, 10: 49. https://doi.org/10.1186/1477-7827-10-49

AGARWAL, A., GUPTA, S. \& SHARMA, R. (2005a) Role of oxidative stress in female reproduction, Reproductive Biology and Endocrinology, 3: 28. https://doi.org/10.1186/14777827-3-28

Malay J Pharm Sci, Vol. 19, No. 2 (2021): 111-130 
AGARWAL, A., GUPTA, S. \& SHARMA, R. (2005b) Oxidative stress and its implications in female infertility-A clinician's perspective, Reproductive BioMedicine Online, 11(5): 641650. https://doi.org/10.1016/s1472-6483(10)61174-1

AMINI L., TEHRANIAN N., MOVAHEDIN M., TEHRANI F. R. \& ZIAEE S. (2015) Antioxidants and management of polycystic ovary syndrome in Iran: A systematic review of clinical trials, Iranian Journal of Reproductive Medicine, 13(1): 1-8.

AZZI, A., GYSIN, R., KEMPNÁ, P., MUNTEANU, A., VILLACORTA, L., VISARIUS, T. et al. (2004) Regulation of gene expression by a-tocopherol, Biological Chemistry, 385(7): 585-591. https://doi.org/10.1515/BC.2004.072

PHINNEY, S. \& VOLEK, J. (2019) Polycystic ovarian syndrome, insulin resistance, and inflammation. https://www.virtahealth.com/blog/pcos-polycystic-ovarian-syndrome

BAILLARGEON, J. P. (2005) Use of insulin sensitizers in polycystic ovarian syndrome, Current Opinion in Investigational Drugs, 6(10): 1012-1022.

BALEN, A. (2004) The pathophysiology of polycystic ovary syndrome: Trying to understand PCOS and its endocrinology, Best Practice \& Research Clinical Obstetrics \& Gynaecology, 18(5): 685-706. https://doi.org/10.1016/j.bpobgyn.2004.05.004

BANCROFT, J. D. \& GAMBLE, M. (2002) Theory and practice of histological techniques, 5th edition, pp. 125-138 (Philadelphia: Churchill Livingstone).

BUETTNER, G. R. (1993) The pecking order of free radicals and antioxidants: lipid peroxidation, alpha-tocopherol, and ascorbate, Archives of Biochemistry and Biophysics, 300(2): 535-543. https://doi.org/10.1006/abbi.1993.1074

CHEN, C., YAN, Q., LIU, K., ZHOU, X., XIAN, Y., LIANG, D. et al. (2016) Endometrial receptivity markers in mice stimulated with raloxifene versus clomiphene citrate and natural cycles, Reproductive Sciences, 23: 748-755.

CICEK, N., ERYILMAZ, O. G., SARIKAYA, E., GULERMAN, C. \& GENC, Y. (2012) Vitamin $E$ effect on controlled ovarian stimulation of unexplained infertile women, Journal of Assisted Reproduction and Genetics, 29(4): 325-328. https://doi.org/10.1007/s10815-012-9714-1

DE LEO, V., LANZETTA, D., D'ANTONA, D., MARCA, A. \& MORGANTE, G. (1998). Hormonal effects of Flutamide in young women with polycystic ovary syndrome, The Journal of Clinical Endocrinology and Metabolism, 83(1): 99-102. https://doi.org/10.1210/ jcem.83.1.4500

DIAMANTI-KANDARAKIS, E. \& DUNAIF, A. (2012) Insulin resistance and the polycystic ovary syndrome revisited: An update on mechanisms and implications, Endocrine Reviews, 33(6): 981-1030. https://doi.org/10.1210/er.2011-1034

DIAMANTI-KANDARAKIS, E., KOULI, C. R., BERGIELE, A. T., FILANDRA, F. A., TSIANATELI, T. C., SPINA, G. G. et al. (1999) A survey of the polycystic ovary syndrome in the greek island of lesbos: Hormonal and metabolic profile, The Journal of Clinical Endocrinology and Metabolism, 84(11): 4006-4011. https://doi.org/10.1210/ jcem.84.11.6148 
DRUG BANK (2011) Clomifene. Updated on April 19, 2011. https://www.drugbank.ca/ drugs/DB00882.

DUNAIF, A., XIA, J., BOOK, C. B., SCHENKER, E. \& TANG, Z. (1995) Excessive insulin receptor serine phosphoryation in cultured fibroblast and in skeletal muscle: A potential mechanism for insulin resistance in the polycystic ovary syndrome, The Journal of Clinical Investigation, 96(2): 801-810. https://doi.org/10.1172/JCI118126

DURAN, J. R. \& RAJA, M. L. (2007) Myocardial infarction in pregnancy associated with clomiphene citrate for ovulation induction: A case report, Journal of Reproductive Medicine. 52(11): 1059-1062.

EBRAHIMI, F. A., SAMIMI, M., FOROOZANFARD, F., JAMILIAN, M., AKBARI, H., RAHMANI, E., et al. (2017) The effects of omega-3 fatty acids and vitamin E co-supplementation on indices of insulin resistance and hormonal parameters in patients with polycystic ovary syndrome: A randomized, double-blind, placebo-controlled trial, Experimental and Clinical Endocrinology and Diabetes, 125(6): 353-359. https://doi.org/10.1055/s-0042-117773

FENKCI, V., FENKCl, S., YILMAZER, M. \& SERTESER, M. (2003) Decreased total antioxidant status and increased oxidative stress in women with polycystic ovary syndrome may contribute to the risk of cardiovascular disease, Fertility and Sterility, 80(1): 123-127. https://doi.org/10.1016/s0015-0282(03)00571-5

FOECKING, E. M., MCDEVITT, M. A., ACOSTA-MARTÍNEZ, M., HORTON, T. H. \& LEVINE, J.E. (2008) Neuroendocrine consequences of androgen excess in female rodents, Hormones and Behavior, 53(5): 673-692. https://doi.org/10.1016/j.yhbeh.2007.12.013

FRATTARELLI, J. L. \& DEMPSEY, M. S. (2004) Characteristics of baseline ovarian cysts in clomiphene citrate ovulation cycles, Fertility and Sterility, 82(4): 979-981. https://doi. org/10.1016/j.fertnstert.2004.02.145

FUJII, J., IUCHI, Y. \& OKADA, F. (2005) Fundamental roles of reactive oxygen species and protective mechanisms in the female reproductive system, Reproductive Biology and Endocrinology, 3: 43-45. https://doi.org/10.1186/1477-7827-3-43

FULGHESU, A. M., CIAMPELLI, M., MUZI, G., BELOSI, C., SELVAGGI, L., AYALA, G. F. et al. (2002) $\mathrm{N}$-acetyl cysteine treatment improves insulin sensitivity in women with polycystic ovary syndrome, Fertility and Sterility, 77(6): 1128-1135. https://doi.org/10.1016/s00150282(02)03133-3

GOODMAN, N. F., COBIN, R. H., FUTTERWEIT, W., GLUECK, J. S., LEGRO, R. S. \& CARMINA, E. (2015) American Association of Clinical Endocrinologists, American College of Endocrinology and, Androgen Excess and PCOS Society disease state clinical review: Guide to the beats practices in the evaluation and treatment of polycystic ovary syndrome Part 1, Endocrine, 21(11): 1291-300. https://doi.org/10.4158/EP15748.DSC

GOODMAN, R. L. (1996) Neural systems mediating the negative feedback actions of estradiol and progesterone in the ewe, Acta Neurobiologiae Experimentalis, 56(3): 727-741.

Malay J Pharm Sci, Vol. 19, No. 2 (2021): 111-130 
HAMAD A. W., AHMAD, S. A. \& RASHEED, F. A. (2011) Comparative study of antioxidant levels (vitamin $E$ \& selenium) in serum of polycystic ovary syndrome patients and control, Journal of Al-Nahrain University, 14(1): 40-43.

HOMBURG, R. (2005) Clomiphene citrate-end of an era? A mini-review, Human Reproduction, 20(8): 2043-2051. https://doi.org/10.1093/humrep/dei042

JADHAV, M., MENON S. \& SHAILAJAN, S. (2013) Anti-androgenic effect of Symplocos racemosa Roxb. against letrozole induced polycystic ovary using rat model, Journal of Coastal Life Medicine, 1(4): 309-314. https://doi.org/10.12980/JCLM.1.2013C79

LAMFON, H. A. \& AL-MATRAFI, S. S. (2013) Clomid induced hormonal and histological alterations in ovary of albino rats, Journal of American Science, 9(12): 39-43.

LEA, R. W., CLARK, J. A. \& TSUTSUI, K. (2001) Changes in central steroid receptor expression, steroid synthesis, and dopaminergic activity related to the reproductive cycle of the ring dove, Microscopy Research and Technique, 55(1): 12-26. https://doi.org/10.1002/ jemt.1152

LERCHBAUM, E., SCHWETZ, V., RABE, T., GIULIANI, A. \& OBERMAYER-PIETSCH, B. (2014) Hyperandrogenemia in polycystic ovary syndrome: Exploration of the role of free testosterone and androstenedione in metabolic phenotype, PLOS ONE, 9(10): e108263. https://doi.org/10.1371/journal.pone.0108263

LOBATO, K., CARDOSO, C., BINFARÉ, R. W., BUDNI, C., WAGNER, L. R., BROCARDO, B. S. et al. (2010) $\alpha$-Tocopherol administration produces an antidepressant-like effect in predictive animal models of depression, Behavioural Brain Research, 209(2): 249-259.

LOMBARDI, L. A., SIMÕES, R. S., MAGANHIN, C. C., BARACAT, M. C. P., SILVASASSO, G. R., FLORENCIO-SILVA, R. et al. (2014) Immunohistochemical evaluation of proliferation, apoptosis and steroidogenic enzymes in the ovary of rats with polycystic ovary, Revista da Associação Médica Brasileira, 60(4): 349-356. https://doi.org/10.1590/18069282.60.04.0014

LOMBARDI, L. A., SIMÕES, R. S., MAGANHIN, C. C., SILVA, C. F., MACIEL, G. A., BARACAT, E. C. et al. (2012) Morphology of the interstitial cells of rat polycystic ovaries: An experimental study, Revista Brasileira de Ginecologia e Obstetricia, 34(7): 323-328.

MANGIALASCHE, F., WESTMAN, E., KIVIPELTO, M., MUEHLBOECK, J. S., CECCHETTI, R., BAGLIONI, M. et al. (2013) Classification and prediction of clinical diagnosis of Alzheimer's disease based on MRI and plasma measures of $\alpha-/ \gamma$-tocotrienols and y-tocopherol, Journal of International Medicine, 273(6): 602-621. https://doi.org/10.1111/ joim. 12037

MIER-CABRERA, J., ABURTO-SOTO, T., BURROLA-MÉNDEZ, S., JIMÉNEZ-ZAMUDIO, L., TOLENTINO, M. C., CASANUEVA, E. et al. (2009) Women with endometriosis improved their peripherals antioxidants markers after the application of a high antioxidant diet; Reproductive Biology and Endocrinology; 7: 54. https://doi.org/10.1186/1477-7827-7-54 
MO, Q., LU, S. F. \& SIMON, N. G. (2006) Dehydroepiandrosterone and its metabolites: Differential effects on androgen receptor trafficking and transcriptional activity, The Journal of Steroid Biochemistry and Molecular Biology, 99(1): 50-58. https://doi.org/10.1016/j. jsbmb.2005.11.011

MONTEIRO, T. H., SILVA, C. S., CORDEIRO SIMÕES AMBROSIO, L. M., ZUCOLOTO, S. \& VANNUCCHI, H. (2012) Vitamin E alters inflammatory gene expression in alcoholic chronic pancreatitis, Journal of Nutrigenet Nutrigenomics, 5(2): 94-105. https://doi. org/10.1159/000336076

NAIDU, J. N., SWAPNA, G. N., KUMAR, A. N., KRISHNAMMA, M. \& ANITHA, M. (2013) Importance of elevated insulin resistance, dyslipidemia and status of antioxidant vitamins in polycystic ovary disease, Free Radicals and Antioxidants, 3: 17-19.

NIPPOLD, T. B. \& NAIR, K. S. (1998) Is there a case for DHEA replacement? Bailliere's Clinical Endocrinology, 12(3): 507-520. https://doi.org/10.1016/s0950-351x(98)80286-3

OAKLEY, O., LIN, P., BRIDGES, P. \& KO, C. (2011) Animal models for the study of polycystic ovarian syndrome, Endocrinology and Metabolism, 26(3): 193-202.

OLECH, E. \& MERRILL, J. T. (2005) DHEA supplementation: The claims in perspective, Cleveland Clinic Journal of Medicine, 72(11): 965-966. https://doi.org/10.3949/ ccjm.72.11.965

OZKAYA, M. \& NAZIROGLU, M. (2010) Multivitamin and mineral supplementation modulates oxidative stress and antioxidant vitamin levels in serum and follicular fluid of women undergoing in vitro fertilization, Fertility and Sterility, 94(6): 2465-2466.

PAIXÃO, L., RAMOS, R. B., LAVARDA, A., MORSH, D. M. \& SPRITZER, P. M. (2017) Animal models of hyperandrogenism and ovarian morphology changes as features of polycystic ovary syndrome: A systematic review, Reproductive Biology and Endocrinology, 15(1):12. https://doi.org/10.1186/s12958-017-0231-z

PALOMBA, S., RUSSO, T., ORIO, F., FALBO, A., MANGUSO, F., SAMMARTINO, A. et al. (2006) Uterine effects of clomiphene citrate in women with polycystic ovary syndrome: A prospective controlled study, Human Reproduction, 21(11): 2823-2829, https://doi. org/10.1093/humrep

PANNILL, M. (2002) Polycystic ovary syndrome, Advanced Practice Nursing e-Journal, 2(3). http://www.medscape.com/viewarticle/438597

PASQUALI, R. \& GAMBINERI, A. (2009) Targeting insulin sensitivity in the treatment of polycystic ovary syndrome, Expert Opinion on Therapeutic Targets, 13(10): 1205-1226.

PASTOR, C. L., GRIFFIN-KORF, M. L., ALOI, J. A., EVANS, W. S. \& MARSHALL, J. C. (1998) Polycystic ovary syndrome: Evidence for reduced sensitivity of the gonadotropinreleasing hormone pulse generator to inhibition by estradiol and progesterone, The Journal of Clinical Endocrinology and Metabolism, 83(2): 582-590. https://doi.org/10.1210/ jcem.83.2.4604

Malay J Pharm Sci, Vol. 19, No. 2 (2021): 111-130 
PAWELCZAK, M., ROSENTHAL, J., MILLA, S., LIU, Y. H. \& SHAH, B. (2014) Evaluation of the pro-inflammatory cytokine tumor necrosis factor- $\alpha$ in adolescents with polycystic ovary syndrome, Journal of Pediatric and Adolescent Gynecology, 27(6): 356-359. https://doi. org/10.1016/j.jpag.2014.01.104

PORETSKY, L., CATALDO, N. A., ROSENWAKS, Z. \& GIUDICE, L. C. (1999) The insulinrelated ovarian regulatory system in health and disease, Endocrine Reviews, 20(4): 535582. https://doi.org/10.1210/edrv.20.4.0374

PRACTICE COMMITTEE OF THE AMERICAN SOCIETY FOR REPRODUCTIVE MEDICINE (2013) Use of clomiphene citrate in infertile women: A committee opinion, Fertility and Sterility, 100(2): 341-348. https://doi.org/10.1016/j.fertnstert.2013.05.033

RAHMAN, K. (2007) Studies on free radicals, antioxidants, and co-factors, Clinical Interventions in Aging, 2(2): 219-236.

RAHMANI, E., SAMIMI, M., EBRAHIMI, F. A., FOROOZANFARD, F., AHMADI, S., RAHIMI, $M$. et al. (2017) The effects of omega-3 fatty acids and vitamin $E$ co- supplementation on gene expression of lipoprotein(a) and oxidized low-density lipoprotein, lipid profiles and biomarkers of oxidative stress in patients with polycystic ovary syndrome, Molecular and Cellular Endocrinology, 439: 247-255.

RAMMOUZ, G., LECANU, L. \& PAPADOPOULOS V. (2011) Oxidative stress-mediated brain dehydroepiandrosterone (DHEA) formation in Alzheimer's disease diagnosis, Frontiers in Endocrinology, 2: 69. https://doi.org/10.3389/fendo.2011.00069

REZVANFAR, M. A., REZVANFAR, M. A., AHMADI, A., SHOJAEI-SAADI, H. A., BAEERI, M. \& ABDOLLAHI, M. (2012) Molecular mechanisms of a novel selenium-based complementary medicine which confers protection against hyperandrogenism-induced polycystic ovary, Theriogenology, 78(3): 620-631. https://doi.org/10.1016/j.theriogenology.2012.03.008

RIZVI, S., RAZA, S. T., AHMED, F., AHMED, A., ABBAS, S. \& MAHDI, F. (2014) The role of vitamin E in human health and some diseases, Sultan Qaboos University Medical Journal, 14(2): e157-e165.

ROE, A. H. \& DOKRAS, A. (2011) The diagnosis of polycystic ovary syndrome in adolescents, Reviews in Obstetrics \& Gynecology, 4(2): 45-51. https://doi.org/10.3909/riog0151

ROSENFIELD, R. L. \& EHRMANN, D. A. (2016) The pathogenesis of polycystic ovary syndrome (PCOS): The hypothesis of PCOS as functional ovarian hyperandrogenism revisited, Endocrine Reviews, 37(5): 467-520. https://doi.org/10.1210/er.2015-1104

RUDER, E. H., HARTMAN, T. J., BLUMBERG, J. \& GOLDMAN, M. B. (2008) Oxidative stress and antioxidants: Exposure and impact on female fertility, Human Reproduction Update, 14(4): 345-357. https://doi.org/10.1093/humupd/dmn011

SEKHON, L. H., SAJAL, G., YESUL, K. \& ASHOK, A. (2010) Female infertility and antioxidants, Current Women's Health Reviews, 6: 84-95. https://doi. org/10.2174/157340410791321381 
SUGINO, N., KARUBE-HARADA, A., TAKTANI, T., SAKATA, A. \& NAKAMURA, Y. (2004) Withdrawal of ovarian steroids stimulates prostaglandin f2alphaproduction through nuclear factor-kB activation via oxygen radicals in human endometrial stromal cells: Potential relevance to menstruation, Journal of Reproduction and Development, 50(2): 215-225. https://doi.org/10.1262/jrd.50.215

TAHAN, G., AYTAC, E., AYTEKIN, H., GUNDUZ, F., DOGUSOY, G., AYDIN, S. et al. (2011) Vitamin $E$ has a dual effect of anti-inflammatory and antioxidant activities in acetic acid-induced ulcerative colitis in rats, Canadian Journal of Surgery, 54(5): 333-338. https://doi.org/10.1503/cjs. 013610

THE AMERICAN SOCIETY OF HEALTH-SYSTEM PHARMACISTS (2017) Clomiphene citrate. https://medlineplus.gov/druginfo/meds/a682704.html

THE ROTTERDAM ESHRE/ASRM-SPONSORED PCOS CONSENSUS WORKSHOP GROUP (2004) Revised 2003 consensus on diagnostic criteria and long-term health risks related to polycystic ovary syndrome (PCOS), Human Reproduction, 19(1): 41-47. https://doi.org/10.1093/humrep/deh098

TRABER, M. G. \& STEVENS, J. F. (2011) Vitamins C and E: Beneficial effects from a mechanistic perspective, Free Radical Biology and Medicine, 51(5): 1000-1013. https://doi. org/10.1016/j.freeradbiomed.2011.05.017

TRABER, M. G. (2006) Vitamin E. IN: M. E., SHILS, M., SHIKE, A. C., ROSS, B., CABALLERO, R., COUSINS (Eds.). Modern nutrition in health and disease, $10^{\text {th }}$ edition, pp. 396-411 (Baltimore, MD: Lippincott Williams \& Wilkins). https://ods.od.nih.gov/factsheets/ VitaminE-HealthProfessional

TRABER, M. G. \& ATKINSON, J. (2007) Vitamin E, antioxidant and nothing more, Free Radical Biology and Medicine, 43(1): 4-15. https://doi.org/10.1016/j.freeradbiomed.2007.03.024

USADI, R. \& FRITZ, M. (2008) Induction of ovulation with clomiphene citrate, The Global Library of Women's Medicine, 1756-2228. https://doi.org/10.3843/GLOWM.10337

WANG, H., WANG, X., ZHU, Y., CHEN, F., SUN, Y. \& HAN, X. (2015) Increased androgen levels in rats impair glucose-stimulated insulin secretion through disruption of pancreatic beta cell mitochondrial function, Journal of Steroid Biochemistry and Molecular Biology, 154: 254-266. https://doi.org/10.1016/j.jsbmb.2015.09.003

ZHANG, T., LIANG, W., FANG, M., YU, J., NI, Y. \& LI, Z. (2013) Association of the CAG repeat polymorphisms in androgen receptor gene with polycystic ovary syndrome: $A$ systemic review and meta-analysis, Gene, 524(2): 161-167. https://doi.org/10.1016/j. gene.2013.04.040

Malay J Pharm Sci, Vol. 19, No. 2 (2021): 111-130 